\title{
Structure and restrictiveness of financial covenants in bond contracts on Catalyst
}

\author{
Bogumila Brycz" \\ Marek Pauka** \\ Natalia Śmieja***
}

\begin{abstract}
Purpose - The aim of the paper is to study the role of financial covenants in contract of bonds quoted on Polish regulated market called Catalyst. We analyze types and features of financial maintenance covenants and their restrictiveness in regard to limiting conflict of interest between shareholders and bondholders.

Design/Methodology/Approach - We review the related literature and conduct research based on hand collected database of covenants.

Findings - We notice that Polish public bond issuers use financial covenants relatively rare. The most common types of financial maintenance covenants are based on balance sheet and determine the greatest acceptable leverage. Issuers usually avoid using performance covenants and if they decide to use it, the threshold value is zero or negative. Neither the number of financial covenants nor financial slack are correlated with seize or leverage of issuers.

Originality/Value - There is a gap in Polish research on bonds contracts' requirements and our study is the first (although introductory) attempt to explore this field which is very popular in foreign studies.
\end{abstract}

Keywords: financial covenant, bond market, financial ratio

\section{Introduction}

The literature on agency problems related to debt financing assumes that the main purpose of using covenants in debt contract is managing the conflict of interests between shareholders and debt holders. The type and range of debt covenants depend on the scope for agency conflict between the two parties. In particular, Smith and Warner (1979) formulate the costly contracting hypothesis according to which there is an optimal set of covenants in debt contract which maximizes the value of the firm. Covenants which are not appropriately designed are unlikely to control potential opportunistic behavior of managers acting on behalf of shareholders. On the other hand, too restrictive covenants are likely to constrain optimal management activities.

\footnotetext{
*dr Bogumiła Brycz, Politechnika Wrocławska, e-mail: bogumila.brycz@pwr.edu.pl

** dr Marek Pauka, Uniwersytet Ekonomiczny we Wrocławiu, e-mail: marek.pauka@ue.wroc.pl

**** mgr Natalia Śmieja, Uniwersytet Ekonomiczny we Wrocławiu, e-mail: natalia.smieja@ue.wroc.pl
} 
A special type of debt covenants is called financial (accounting-based) covenant. It bases on financial numbers (financial ratios). In many papers authors indicate that their influence on the relations between debt holders and shareholders is different from descriptive covenants. There are many research problems related to financial covenants, but the variety of used formulas makes the analysis technically more complicated.

In this study, we provide evidence of financial covenants associated with Polish public debt market for a sample of the bonds quoted on the Catalyst market since its foundation in 2009 until the end of 2012. We examine the type and frequency of financial covenants in these bond contracts and we also provide evidence on the restrictiveness of the financial covenants in Polish bond contracts. This study is related to the literature concerning the role and types of covenants and their restrictiveness and our study fills the gap in financial covenants analysis on the Polish regulated bond market. It provides evidence for diversity of formulas used to calculate financial covenants which is direct result of the lack of covenant standards on the Polish market and which creates problems to set an effective package of covenants. The aim of the paper is to analyze whether the role of financial covenants in bond contracts is relevant.

The rest of the paper is organized as follows. The next section provides an outline of the extant literature. Section 2 describes the sample and research methodology. In section 3. we analyze financial covenants included in bond contracts, and shade some light on their purpose and potential benefits of including covenants in bonds contracts. We also try to analyze restrictiveness of the financial covenants. The last section contains conclusions.

\section{Review of the literature}

Debt financing creates an agency problem between shareholders and debt holders (see e.g. Gajdka 2002). The conflict of interest between the two parties arises because managers, acting on behalf of shareholders, can have incentives to take actions that increase wealth of shareholders at the expense of debt holders. The most common ways in which managers can expropriate wealth from debt holders are (see e.g. Jensen, Meckling 1976, Smith and Warner 1979, Bradley, Roberts 2004):

1. asset substitution - investing in projects of higher risk than accepted by debt holders,

2. underinvestment - refusing to take positive net present value projects which benefit only the debt holders and not the shareholders,

3. dividend payment - increasing payments to shareholders in the form of dividends or share repurchases and financing the payments by selling assets or reducing investments,

4. claim dilution - issuing new debt of equal or higher priority than existing debt.

The theory of agency problems developed by Jensen and Meckling (1976) and expanded by Myers (1977), Smith and Warner (1979), among others, suggests that the conflict of interest between shareholders and debt holders can be reduced by including appropriate 
covenants in debt contracts that restrict management's future actions. Violation of covenants is commonly referred as technical default and gives investors certain rights indicated in the debt contract like the right to require early repayment. Therefore, covenants are designed to protect investors from possible opportunistic behavior of managers and therefore to lower the firm's cost of debt [see e.g. Smith, Warner 1979, Bradley, Roberts 2004, Moir, Sudarsanam 2007, Reisel 2010].

Covenants can be divided into three basic forms [Day, Taylor 1998]:

- negative covenants - terms under which a borrower agrees not to take certain actions which might adversely affect the status of the claims of the investor such as issue additional debt or sell certain assets,

- positive covenants - terms which aim to provide security to the investors by requiring the borrower to continue with certain specified actions such as provide periodic financial and other information,

- financial covenants (also called as accounting-based covenants) - terms which constitute minimum or maximum level of accounting figures related for example to liquidity and profitability. They can be expressed in relative or absolute value and take the form of positive or negative covenants.

Researchers suggest that covenants are often based on accounting measures. On the basis of the literature review we can indicate three main study areas on financial covenants concerning the following:

- determinants and role of financial covenants,

- restrictiveness of financial covenants,

- violation of financial covenants.

This paper is related to the first two study areas which focus on the types and frequency of financial covenants, their role in debt contract as well as on the factors that determine the occurrence and restrictiveness of financial covenants. As Demerjian and Owens notice "the selection and strictness of covenants should play a complementary role in providing protection to the creditor, specifically through the channel of technical default" (Demerjian, Owens 2013).

Citron (1995) examining the incidence of accounting-based covenants in UK public debt issued during the period 1987-1990 states that among 108 public contracts 30\% contain accounting-based covenants majority of which are gearing covenants. The author notices that while in US public debt covenants are almost universally negative in UK there are more affirmative covenants. Citron finds that the presence of accounting-based covenants in UK public contracts is associated with long-term unsecured debt and high values for assets-inplace but is unrelated to gearing. The author also suggests that convertibility reduces the need for accounting-based covenants, especially when the debt is also subordinated (subordinated convertible agreements indicate strong alignment of the debt holders' interests with those of the shareholders). Moir and Sudarsanam (2007) examining financial covenants associated with private debt for a sample of 72 UK corporate borrowers report that $53 \%$ use one or two financial covenants. The authors observe the dominance of covenants relating to gearing, 
interest cover and minimum tangible net worth but they emphasize that there is some small trend towards using cash flow-based measures. Their results indicate that among such firmrelated characteristics as size, reputation, risk or liquidity only the borrower size significantly influences the decision of borrowers to provide these covenants. The authors conclude that UK banks seem to treat size as a proxy for the financial strength and reputation of borrowers, what contributes to reduce their agency problem with the latter. In the US Bradley and Roberts (2004) examining 12425 private corporate loans provided to 3012 firms during the period 1993-2001 report that the sample of loans contains covenants on 17 different accounting variables and there are 2,5 financial measures contained in loan on average, with the most popular covenants restricting the ratio of debt to operating income and tangible net worth. In a number of loans, the financial covenants contain a "trend," in that the threshold is changed over the life of the loan. Demerjian (2011) examining the sample of 8,527 private debt agreements of publicly traded, non-financial borrowers found out that over the period from 1996 to 2007 the income statement covenants (covenants based on income statement variables such as interest coverage, fixed charge coverage and debt-to-earnings covenants) were included in between $74 \%$ and $82 \%$ of deals, and the balance sheet covenants (covenants based on balance sheet variables such as leverage, net worth, and current ratio covenants) were included in more than $80 \%$ of the debt contracts in 1996 but in the next years their use declined to $32 \%$ of deals in 2007 . The author concludes that the decline in use of balance sheet covenants is associated with changes in accounting standards which made the balance sheet less useful for contracting. Christensen and Nikolaev (2011) focus in their research on examining the role of accounting-based covenants in limiting agency costs and they classify covenants into two groups: capital covenants which are based on information about sources and uses of capital (balance sheet information only) and performance covenants which are formulated in terms of current-period profitability and efficiency indicators. The authors argue that the two groups of covenants reduce agency costs in two different ways. Capital covenants align the interests of shareholders and debt holders by restricting the level of debt in a firm's capital structure directly and because they demand appropriate level of equity capital shareholders' wealth is sensitive to opportunistic actions that decrease firm value. On the contrary, performance covenants prevent suboptimal managerial actions by reallocating control to debt holders when they are at risk of expropriation their wealth. This type covenants act as tripwires, or timely indicators of weak performance. Christensen and Nikolaev provide evidence that financially constrained firms use performance rather than capital covenants (the latter require a certain level of equity capital and therefore reduce financial flexibility which is problematic for financially constrained borrowers ). On the other hand the authors find that the use of capital covenants increases (relative to performance covenants) when contractibility of accounting information declines (performance covenants are effective if the accounting information is contractible). They also find that performance covenants are used in combination with negative covenants which restrict managers' actions. It is worth to note that this classification is related to the classification on balance sheet and income statement covenants made by Demerjian but Christensen and 
Nikolaev prefer the labels "capital" and "performance" because they better describe the economic nature of these covenants and the underlying mechanisms through which they address agency problems and furthermore the authors claim that classifying some covenants to the group of balance sheet or income statement covenants is somewhat arbitrary. Achleitner et al. (2012) indicate that financial covenants can be classified into two fundamental types: incurrence and maintenance financial covenants. Incurrence financial covenants restrict the actions of borrowers that might extract wealth from debt holders (like an acquisition or an issuance of additional debt) if certain accounting-based thresholds are not satisfied. Whereas issuers have to meet maintenance financial covenants on an ongoing basis over the term of the debt and it is independent of their actions to transfer wealth. The authors examine the structure and determinants of financial covenants in leveraged buyouts and they indicate that leveraged loans traditionally use maintenance financial covenants but if credit markets is overheated leveraged loans might incorporate incurrence covenants instead of maintenance covenants. Cotter (1998) examining the types of covenants typically used in bank loan agreements of listed Australian firms indicates that the most frequently used accounting based covenants in Australian bank loan agreements are leverage, interest coverage, prior charges and current ratios. The utilization and restrictiveness of these covenants varies with firm size and industry. Larger firms tend to have less restrictive covenants than smaller firms, while industrial firms tend to have less restrictive covenants than mineral producers.

As regards restrictiveness of debt covenants researchers use different measures to assess it. In early studies we meet the level of debt as a proxy of the restrictiveness of the debt covenants (Begley, Feltham 1999). Other researchers use the number of covenants in the debt contract assuming that greater number means higher restrictiveness (see e.g. Bradley, Roberts 2004). However, we agree with Demerjian and Owens (2013) that although it is possible that more covenants may mean more overall strictness, this is not necessarily always true. For example, a debt contract with one tightly set covenant could more likely to be violated than a debt contract with three loosely set covenants. The restrictiveness of financial covenants is also measured by examining how tightly these covenants are set, i.e. by measuring the covenant slack which is defined as a "difference between the threshold value and the initial value of the financial covenant measure" (Demerjian, Owens 2013). Measuring the covenant slack is sometimes difficult because databases used by researchers very often do not provide specific definition of the ratios used in financial covenants. Therefore, in order to conduct their analysis some researchers use only these financial covenants which are most homogenously measured. For example Dichev and Skinner (2002) chose only the current ratio and net worth covenants since these ratios are widely used and have the most standard definitions among all financial covenants. The authors report that in private debt the covenants are set tightly relative to likely variation in these financial measures over the life of the loan. Demiroglu and James (2010) also chose two financial covenants: the minimum current ratio covenant and the maximum Debt/EBITDA because these covenants were common and economically important and because authors could measure the tightness of the covenants most reliably. The authors conclude that riskier borrowers and those with less valuable growth options are more likely to accept tight financial covenants. Demiroglu 
and James also suggest that covenants are set tightly when performance is expected to improve and when investment spending and net debt issuance decline.

To summarize, in our research empirical focus is to provide evidence on the incidence of financial covenants in Polish public bond contracts. This paper examines what types and how frequently the issuers use financial covenants and how tightly these covenants are set.

\section{Sample and research method}

Although bond market in Poland operates for more than 20 years, only in recent years, after starting the Catalyst this segment of the financial market has become accessible to the average individual investors, as the stock market previously. Former the bond market was limited to institutional investors and large individual investors. They could afford to conduct preliminary analyzes.

The sample used in our research covers financial covenants coming from the issue terms of Polish corporate bonds quoted on the Catalyst market from the beginning of its operation, i.e. from September 2009 to the end of 2012. Debt contract information was hand-collected from indentures or prospectuses. We excluded documents prepared by the banks and issues for which the companies did not disclose the terms of the issue. Finally we gathered data on 3484 covenants from 240 series of bonds issued by 110 issuers. It should be emphasized that several covenants are indicated in the Bonds Act (as compulsory / statutory) and these covenants were not included in our research.

After creating the database of covenants, we make their classification (as described in the next Section) and conducted in-depth research of maintenance financial covenants only. We indicated two types of financial ratios embedded in these covenants and therefore we distinguished capital covenants and performance covenants. Finally, a detailed analysis encompassed 196 maintenance covenants. We analyze types, construction and frequency of these covenants as well as we examine their restrictiveness. As indicated in the literature review researchers use different measures of restrictiveness. We measure the covenant slack by calculating the level of "safety cushion" between the value of financial ratio used as covenant and its value for annual data from the last accessible annual report before bond issuance (from the perspective of potential bond holder on the primary market). We think if the slack is larger the covenant is less restrictive because the firm's financial measure can be deteriorated within the wider range before it causes covenant violation.

\section{Research and results}

We analyze covenants in the Polish bond issues introduced on the Catalyst market using a multi-stage classification shown in the Figure 1. Covenants are divided into two groups: descriptive and financial covenants. We define the financial covenant as requirement based 
on financial measures calculated on the basis of the financial statements. Among the financial covenants we distinguish two types of covenants: incurrence and maintenance, depending on their impact on the operation of the board, which was mentioned in the second part of the paper. We treat payout and buy back covenants as incurrence ones. A violation of incurrence covenants is easy to avoid, so they have a minor value for debt holders in comparison to maintenance covenants and as consequence incurrence financial covenants are not the focus of academic research (Tappeiner, 2010). In our detailed analysis we also focus only on maintenance covenants dividing them into two types: capital covenants and performance covenants, as proposed by Christensen and Nikolaev (2011).

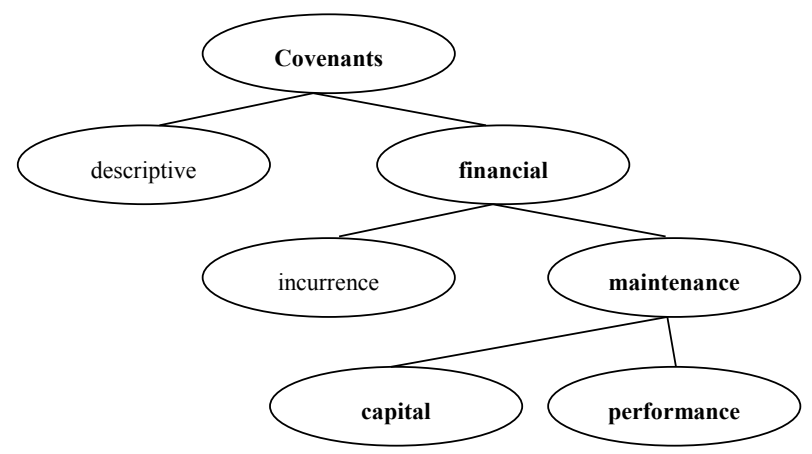

Figure 1. Types of covenants

Source: own construction.

As indicated in the literature review (Section 2), financial covenants are the focus of the academic research which suggest that they are often used playing an important role in limiting conflicts between shareholders and debt holders. However, when analyzing bonds traded on the Polish Catalyst market we can observe that issuers use financial covenants rarely. This group of covenants is represented by 166 financial incurrence covenants and 196 financial maintenance covenants among all 3483 identified covenants. Because our detailed analysis encompasses only maintenance covenants, henceforth they will be called simply financial covenants. Figure 2 shows the frequency of occurrence of this group of covenants. Almost half of the bond series (47.9\%, i.e. 115 cases of the 240 series) have no financial covenants at all. In comparison, recent studies on financial covenants used in loans of non-bank large listed French firms over the period of 2003-2009 show that these covenants are present in $63,7 \%$ of the French debt contracts (Ismail, 2014). In our sample $29,2 \%$ of bond issues has only one financial covenant. In case of one bond contract issuer applied the maximum number of financial covenants (i.e. four covenants). The average number of total covenants amounts 14.5 (median 12) per issuance while the average number of financial covenants amounts 0.8 per issuance (median 1). The average share of financial covenants in the total covenants is $5.6 \%$. 


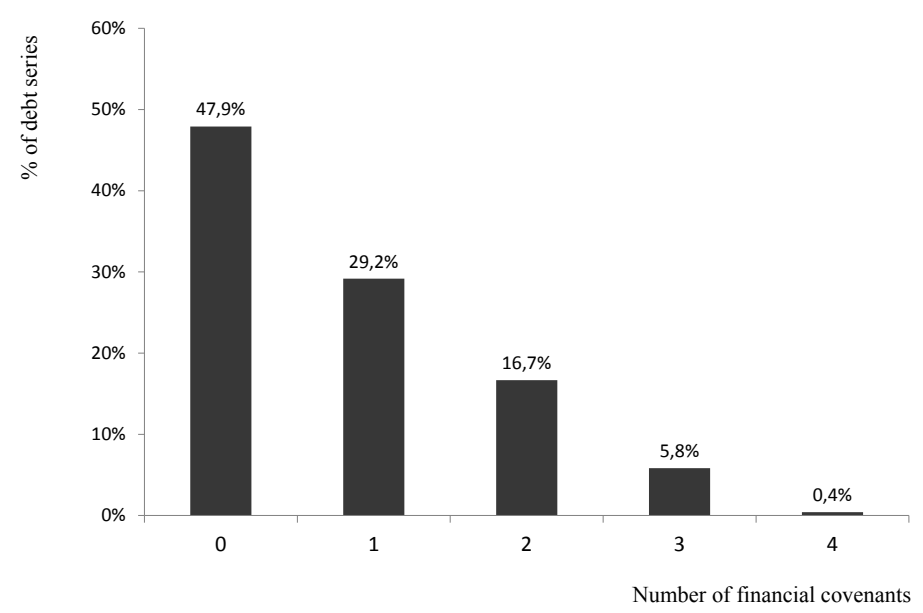

Figure 2. Number of financial covenants in bond indentures Source: own calculation.

The examined group of financial covenants consists of:

- capital covenants (132 cases in 117 issues, it is $67,3 \%$ of all financial covenants).

- performance covenants (64 cases in 54 issues, it is $32,7 \%$ of all financial covenants).

The different types and definitions of capital and performance covenants used in our sample are given in Table 1. In the group of capital covenants we can observe two broad categories: covenants that require to maintain certain minimum level of working capital during the life of the bond and covenants that require to maintain certain relation debt and equity. In the group of performance covenants we can also find two broad categories: covenants that require to maintain certain minimum level of profitability and covenants that require a firm to maintain certain ability to meet its financial obligations.

Overall we identify 14 types of financial covenants ( 8 types of capital covenants and 6 types of performance covenants) but we notice considerable variation in the degree of standardization in covenant measurement. In particular, it refers to debt to equity ratio and ratio of debt to EBITDA where we observe different variables in the numerator of these ratios and large diversity in defining the level of liabilities or debt. In addition to the exclusions in the form of liabilities to related entities, some companies overlook the non-financial liabilities or reduce the level of liabilities by the cash (net debt). Among developers we can find the characteristic correction of liabilities. Liquidity and profitability covenants are homogenously measured. The debt-to-assets ratio in turn doesn't show large diversity. Although there are three different definitions in our bond sample, the vast majority of issuers use its basic form, i.e. total liabilities divided by total assets. In the case of profitability covenants there are mainly covenants that require to maintain a minimum level of selected type of earnings and we can notice very conservative setting of thresholds for these covenants. 
Table 1.

Financial covenants classification and measuring formula

\begin{tabular}{|c|c|c|c|}
\hline & Type of ratio & Formula's variants & Possible exclusions \\
\hline \multirow{14}{*}{ 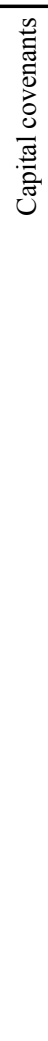 } & \multicolumn{3}{|l|}{ I. Liquidity covenants } \\
\hline & 1. Current ratio & Current Assets/Current Liabilities & $\mathrm{n} / \mathrm{a}$ \\
\hline & 2. Others & Current Assets/Total Liabilities & $\mathrm{n} / \mathrm{a}$ \\
\hline & \multicolumn{3}{|l|}{ II. Capital structure covenants } \\
\hline & \multirow[t]{3}{*}{ 3. Debt to Asset Ratio } & Total debt/Total Assets & \multirow{3}{*}{$\begin{array}{l}\text { Exclusions to debt: } \\
\text { - Non-financial liabilitites, } \\
\text { - short-term liabilitites } \\
\text { - subordinated debt }\end{array}$} \\
\hline & & $\begin{array}{l}\text { (Total debt }- \text { cash and } \\
\text { equivalents)/Total Assets }\end{array}$ & \\
\hline & & $\begin{array}{l}\text { (Financial debt - cash and } \\
\text { equivalents)/Total Assets }\end{array}$ & \\
\hline & \multirow[t]{3}{*}{ 4. Debt to Equity Ratio } & debt/ equity & \multirow{3}{*}{$\begin{array}{l}\text { Exclusions to debt: } \\
\text { - non-interest (non-financial) debt } \\
\text { - unearned revenue/accruals } \\
\text { - subordinated line of credit treated } \\
\text { as equity } \\
\text { Exclusions to equity: } \\
\text { - minority interest } \\
\text { - intangible assets and positive firm } \\
\text { value } \\
\text { - non-cash contribution }\end{array}$} \\
\hline & & $\begin{array}{l}\text { (debt - cash and equivalents)/ } \\
\text { equity }\end{array}$ & \\
\hline & & $\begin{array}{l}\text { (Financial debt - cash and } \\
\text { equivalents)/ equity }\end{array}$ & \\
\hline & 5. Equity to Debt Ratio & equity/Total debt & $\mathrm{n} / \mathrm{a}$ \\
\hline & 6. Equity to Asset Ratio & equity /Total Assets & $\mathrm{n} / \mathrm{a}$ \\
\hline & 7. Level of Equity & Book value of equity & $\mathrm{n} / \mathrm{a}$ \\
\hline & 8. Level of Liabilities & Value of liabilities & $\begin{array}{l}\text { Exclusions to liabilities: } \\
\text { - non-financial liabilities } \\
\text { - provisions } \\
\text { - accruals }\end{array}$ \\
\hline \multirow{11}{*}{ 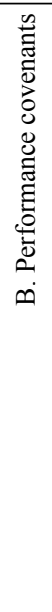 } & \multicolumn{3}{|l|}{ I. Profitability Covenants } \\
\hline & Level of operating income & $\begin{array}{l}\text { Value of earnings from operating } \\
\text { activities }\end{array}$ & $\mathrm{n} / \mathrm{a}$ \\
\hline & Level of EBITDA & Value of EBITDA & $\mathrm{n} / \mathrm{a}$ \\
\hline & Level of net earnings & Value of net earnings & $\mathrm{n} / \mathrm{a}$ \\
\hline & EBITDA to sales ratio & EBITDA/Sales & $\mathrm{n} / \mathrm{a}$ \\
\hline & \multicolumn{3}{|l|}{ II. Coverage ratio covenants } \\
\hline & \multirow[t]{3}{*}{ 5. Ratio of debt to EBITDA } & Debt/EBITDA & \multirow{3}{*}{$\begin{array}{l}\text { Adjustments to debt: } \\
\text { - off-balance sheet debt } \\
\text { Adjustments to EBITDA: } \\
\text { - One-off costs and revenues }\end{array}$} \\
\hline & & $\begin{array}{l}\text { (debt - cash and equivalents)/ } \\
\text { EBITDA }\end{array}$ & \\
\hline & & $\begin{array}{l}\text { (financial debt - cash and } \\
\text { equivalents)/EBITDA }\end{array}$ & \\
\hline & \multirow[t]{2}{*}{ 6. Interest coverage ratio } & EBITDA/interest expense & $\mathrm{n} / \mathrm{a}$ \\
\hline & & EBITA/interest expense & $\begin{array}{l}\text { Exclusions to EBITDA: } \\
\text { depreciation }\end{array}$ \\
\hline
\end{tabular}

Source: own elaboration. 
In most cases the minimum level was zero or even negative value of earnings, which in principle excludes the use of profitability ratios (instead of absolute value) in covenants. There are only small and medium size companies among issuers which use positive value of such profitability covenants. Such conservative thresholds may suggest that management concerns before obligation to use the raised capital in more efficient way and we think that in developing countries (as Poland) small companies have more trouble to maintain stable results.

The Table 2. presents the sample of frequency of each of the 14 types of financial covenants. There are 125 bond issues in which we can find financial covenants. What is characteristic for Polish bonds indentures, capital covenants are much more popular than performance covenants. If we analyze only financial covenants, there are sets of capital and performance covenants in 46 series of issues, and in the 71 issues there are capital covenants alone. In contrast, performance covenants appears alone only in 8 indentures. This evidence is not consistent with some other studies, for example Demerjian (2011) finds sharp decline in using covenants measured with balance-sheet variables in 1996-2007 and he explains this phenomenon by changes in accounting standards, which reduce the usefulness of the balance sheet for debt contracting. The majority of capital covenants in our sample limit the level of debt. Among them the most popular covenant is based on debt-to-equity ratio. This type of financial covenants is indicated as common also in other research cited earlier (e.g. Day and Taylor 1996, Moir, Sudarsanam 2007). This result is consistent with agency theory of financial covenants because capital covenants limit agency conflict between shareholders and debt holders by requiring shareholders to maintain a certain level of their own capital in financing a firm and thus it is not in the interest of shareholders to take actions that decrease firm's value. Analyzing capital covenants we also find that in contrast to other studies Polish bond issuers do not use tangible net worth covenant and rarely use working capital covenant. Regarding to performance covenants which require to maintain a minimum level of the firm's efficiency (profitability) and are treated as early indicators of deterioration in credit quality we can notice that in our sample performance covenants are used two times less than capital covenants. It is characteristic, similarly to other studies, the most popular covenant in this group of covenants is based on the ratio of debt to EBITDA (many research indicate that this ratio is most common of all the financial covenants). The second most popular (in our sample) performance covenant is that requiring a firm to maintain a minimum level of operating income but as we noticed earlier the threshold of this covenant is set very conservatively because in all bond issues using this covenant the threshold has negative value. As the main concern of debt holders is the availability of cash to repay their money they can be interested in covenants relating to cash flow. However in our sample we cannot observe covenants which take into account free cash flow but only covenants relating to EBITDA which can be treated as a proxy of cash flow. In summary, the results suggest that issuers on Polish bond market prefer to use capital rather than performance covenants in order to limit shareholders-bondholders conflict of interests but it also means that the firm's performance can be insufficiently profitable because as long as shareholders maintain enough capital this type of covenants will not be violated. The small 
number of performance covenants and type of their character (types of ratios and threshold value) suggest that bond issuers do not want to apply indicators which monitor their efficiency. Violation of the latter type of covenants cannot be avoided simply by maintaining enough equity capital (for example by not paying dividends).

\section{Table 2.}

Financial covenants frequency

\begin{tabular}{|c|c|c|c|c|c|}
\hline Type of covenants & Frequency & $\begin{array}{l}\text { Number } \\
\text { of bonds with } \\
\text { covenants }\end{array}$ & Type of covenants & Frequency & $\begin{array}{l}\text { Number } \\
\text { of bonds with } \\
\text { covenants }\end{array}$ \\
\hline A. Capital covenants & $67,3 \%$ & $117 *$ & $\begin{array}{l}\text { A. Performance } \\
\text { covenants }\end{array}$ & $32,7 \%$ & $54 *$ \\
\hline I. Liquidity covenants & $4,1 \%$ & $7 *$ & $\begin{array}{l}\text { I. Profitability } \\
\text { Covenants }\end{array}$ & $18,4 \%$ & $34 *$ \\
\hline 1. Current ratio & $3,6 \%$ & 6 & $\begin{array}{l}\text { 1. Level of operating } \\
\text { income }\end{array}$ & $10,2 \%$ & 19 \\
\hline 2. Others & $0,5 \%$ & 1 & 2. Level of EBITDA & $3,6 \%$ & 7 \\
\hline $\begin{array}{l}\text { II. Capital structure } \\
\text { covenants }\end{array}$ & $63,2 \%$ & $115^{*}$ & $\begin{array}{l}\text { 3. Level of net } \\
\text { earnings }\end{array}$ & $4,1 \%$ & 7 \\
\hline 1. Debt to Asset Ratio & $15,3 \%$ & 29 & $\begin{array}{l}\text { 4. EBITDA to sales } \\
\text { ratio }\end{array}$ & $0,5 \%$ & 1 \\
\hline 2. Debt to Equity Ratio & $35,2 \%$ & 69 & $\begin{array}{l}\text { II. Coverage ratio } \\
\text { covenants }\end{array}$ & $14,3 \%$ & $27^{*}$ \\
\hline 3. Equity to Debt Ratio & $3,1 \%$ & 6 & 1. Debt to EBITDA & $12,8 \%$ & 25 \\
\hline 4. Equity to Asset Ratio & $7,1 \%$ & 14 & $\begin{array}{l}2 . \text { Interest coverage } \\
\text { ratio }\end{array}$ & $1,5 \%$ & 3 \\
\hline 5. Level of Equity & $1,5 \%$ & 2 & & & \\
\hline 6. Level of Liabilities & $1,0 \%$ & 2 & & & \\
\hline
\end{tabular}

* One bond contract can contain more than one covenant.

Source: own calculations.

Based on the characteristics of capital covenants and performance covenants and mechanisms in which they mitigate the conflicts of interest between shareholders and debt holders we predict that since capital covenants limit the use of debt they will be negatively associated with the level of debt, i.e. firms with limited access to capital do not want to restrict their flexibility in raising capital. We divided our database of issuers according to quartiles which indicated four group of issuers with different level of debt to asset ratio. The Table 3. shows that, consistent with our prediction, with increasing level of debt the average number of capital covenants decreases. As regards the performance covenants we do not observe the inverse relationship, i.e. the use of covenants is not positively associated with the level of debt but this may be due to the fact that performance covenants are relatively rarely used by Polish issuers (there are only 64 performance covenants in our sample). 
Table 3.

Number of C-covenants and P-covenants related to Debt to Asset Ratio (DA ratio)

\begin{tabular}{lllllll}
\hline \multirow{2}{*}{$\begin{array}{l}\text { Group } \\
\text { of is- } \\
\text { suers }\end{array}$} & C-covenants & \multicolumn{5}{c}{ P-covenants } \\
\cline { 2 - 7 } & DA ratio & $\begin{array}{l}\text { Numbers } \\
\text { of issuers }\end{array}$ & $\begin{array}{l}\text { Average } \\
\text { number } \\
\text { of covenants }\end{array}$ & DA ratio & $\begin{array}{l}\text { Numbers of } \\
\text { issuers }\end{array}$ & $\begin{array}{l}\text { Average } \\
\text { number } \\
\text { of covenants }\end{array}$ \\
\hline I & $<0-51,3 \%>$ & 33 & 1,24 & $<0-51,3 \%>$ & 14 & 1,00 \\
\hline II & $(51,3 \%-59,0 \%>$ & 29 & 1,14 & $(51,3 \%-59,0 \%>$ & 13 & 1,54 \\
\hline III & $(59,0 \%-67,2 \%>$ & 29 & 0,93 & $(59,0 \%-67,2 \%>$ & 13 & 1,15 \\
\hline IV & $(67,2 \%-100,0 \%>$ & 32 & 0,91 & $(67,2 \%-100,0 \%>$ & 13 & 1,08 \\
\hline
\end{tabular}

Source: own calculations.

We also examine the level of restrictiveness of selected covenants. We use the safety margin method (so-called 'slack'). Ratios were calculated on the basis of recent annual financial reports available to investors prior to the issue. If further issues were carried out under the same conditions and on the basis of the same annual reports, covenants included in those bond contracts were excluded from the analysis. Guided by the solutions from other papers, we choose the indicators that are the most frequent and relatively easy to calculate. For this reason, the slack has been conducted for: debt-to-assets ratio and debt-to-equity ratio. They both represent the type of capital covenants. We don't use performance covenants for three reasons. Firstly, some covenants take absolute value rather than relative value (ratios). Otherwise, threshold equals zero or have negative value. Finally, we have problems with collecting data to conduct value for the most popular performance covenant, i.e. debt-to-EBITDA ratio, because of diversity of definitions and numerous exemptions.

In Table 4 we show statistics for debt-to-assets ratio (DA). The average level of activation (threshold) was set at $68 \%$, with the range of $50 \%-85 \%$. To cross the threshold (DA*), average value of ratio should increase by $69 \%$ on average. In other words, ratio of the last year before bond issue (DA) represents on average $73 \%$ of the threshold with the range from $15.84 \%$ to $98.1 \%$. We conclude that the debt to assets ratio was used for issuers who have various capital structures.

\section{Table 4.}

Statistics on slack for the debt to assets ratio covenant.

\begin{tabular}{lcccc}
\hline Descriptive statistics & DA & DA* & $($ DA*-DA)/DA & DA/DA* \\
\hline Minimum & 0,08 & 0,50 & $1,9 \%$ & $\mathbf{1 5 , 8 \%}$ \\
\hline Maximum & 0,75 & 0,85 & $531,3 \%$ & $\mathbf{9 8 , 1 \%}$ \\
\hline Mean & 0,51 & 0,68 & $\mathbf{6 9 , 1 \%}$ & $\mathbf{7 3 , 1 \%}$ \\
\hline Standard deviation & 0,18 & 0,08 & $119,8 \%$ & $\mathbf{2 2 , 8 \%}$ \\
\hline Number of covenants & 26 & & & \\
\hline
\end{tabular}

Source: own calculation. 
Slack counted for the debt-to-equity ratio, shown in Table 5 indicates that the average ratio of the last year (DE) represents $34.3 \%$ of the threshold with range from $-8.5 \%$ to $78.7 \%$ of the threshold. A negative value is due to the fact that in some cases net debt (debt minus cash) was negative. Also in this case there is a large variability of slack, but the average level of ratio $\mathrm{DE}$ to $\mathrm{DE}^{*}$ is much closer to the minimum value compared to the proportion between DA and DA*, which may indicate that the debt-to-equity ratio was preferred by companies with a higher level slack (lower leverage).

Table 5.

Statistics on slack for the debt to equity ratio covenant.

\begin{tabular}{lrrlc}
\hline Descriptive statistics & \multicolumn{1}{l}{ DE } & \multicolumn{1}{c}{ DE* } & $(\mathrm{DE} *-\mathrm{DE}) / \mathrm{DE}$ & $\mathbf{D E} / \mathbf{D E}{ }^{*}$ \\
\hline Minimum & $-0,15$ & 1,00 & $-22,9$ & $\mathbf{- 8 , 5 \%}$ \\
\hline Maximum & 1,82 & 4,00 & 345,8 & $\mathbf{7 8 , 7 \%}$ \\
\hline Mean & 0,73 & 2,05 & $\mathbf{2 6 , 4}$ & $\mathbf{3 4 , 3 \%}$ \\
\hline Standard deviation & 0,63 & 0,68 & 85,8 & $\mathbf{2 6 , 4 \%}$ \\
\hline Number of covenants & 21 & & & \\
\hline
\end{tabular}

Source: own calculation.

After careful analysis of the slack for both ratios, we can conclude that there is no significant relationship between slack and the level of additional interest rate (margin above the level of interest from the interbank money market, i.e. WIBOR). Similar results were found out in other studies focused on debt collection companies (Pauka, Śmieja 2013). And finally we examined that slack is also not dependent on the level of debt or the size of issuers.

\section{Conclusions}

This research investigates accounting-based debt covenants contained in indentures of bonds quoted on Catalyst market in Poland. Results from our research indicate that the role of financial covenants on Polish bond market is limited. We evidence that the frequency of financial covenants is surprisingly low. The most widely used financial covenants are capital covenants based on balance sheet which are relative easy to circumvent by raising equity. We notice that Polish issuers don't use covenants based on cash flow ratios and interest or debt coverage ratios appear in indentures very rarely, independently of size and value of raised capital. Such sets of covenants provide week credit risk protection for bondholders but involve equity capital to a greater extent and mitigate conflict between shareholders and bondholders. But it is low restrictive for management because it's relatively easy to avoid violation of covenants. Finally, capital covenants demand only appropriate level of equity, but in contrast performance covenants pressure management to ensure good results (high profitability) which are more difficult to achieve. 
From investors' perspective, the acceptance for such sets of covenants suggests that they are more afraid of that main owners will exit the company (after making the company highly leverage) leaving them with "empty shell", than the company will not be able to pay back debt. We think that each next case of default on the bond market will shift the investors' attention to guarantee performance covenants (in form of coverage ratios) in set with capital covenants.

Lack of association between the number of covenants and issuers' financial situation as we show in the paper, may be the result of scattering bondholders. In case of loan agreements, the contracts are individually negotiated between private lenders and corporate borrowers and therefore they allow for customizing the financial covenants. Bond indentures use "boiler-plate" of financial covenants. In consequence the restrictiveness of selected financial (capital) covenants varies and we cannot propose any rules or dependences. We believe the problem should be studied deeper.

Presented paper is the introduction to the broader analysis of the role of covenants in the Polish bond contracts. In publications devoted to debt market in other countries, the authors emphasize the significant role of the financial covenants in reducing agency costs and in reducing credit risk. In the case of the Catalyst market, we cannot examine such role due to the sample size (still not sufficiently large). In further studies we will focus on the impact of the characteristics of issuers in the presence of financial covenants (broken down into capital and performance types), restrictiveness and to study so cold stickiness of covenants.

\section{Literature}

Achleitner A.K., Braun R., Hinterramskogler B, Tappeiner F. (2012), Structure and determinants of Financial Covenants in Leveraged Buyouts, "Review of Finance", Vol. 16, pp. 647-684.

Begley J., Feltham G.A. (1999), An empirical examination of the relation between debt contracts and management incentives, "Journal of Accounting and Economics", Vol. 27, Issue 2, pp. 229-259.

Bradley M., Roberts, M.R. (2004), The Structure and Pricing of Corporate Debt Covenants, 6th Annual Texas Finance Festival, dostępny na SSRN: http://ssrn.com/abstract=585882.

Christensen H.B., Nikolaev V.V. (2011), Capital versus Performance Covenants in Debt Contracts, Chicago Booth Research Paper No. 11-06, available at SSRN: http://ssrn.com/abstract=1747909.

Citron D.B. (1995), The Incidence of Accounting-Based Covenants in UK Public Debt Contracts: an Empirical Analysis, "Accounting and Business Research", Vol. 25(99), pp. 139-150.

Cotter J. (1998), Utilisation and restrictiveness of covenants in Australian private debt contracts.

Day J.F.S., Taylor P.J. (1996), Loan contracting by UK corporate borrowers, “Journal of International Banking Law", pp. 318-325.

Day J., Taylor P. (1998), The Role of Debt Contracts in UK Corporate Governance, "Journal of Management and Governance", Vol. 2, pp. 171-190.

Demerjian P.R. (2011), Accounting standards and debt covenants: Has the "balance sheet approach" led to a decline in the use of balance sheet covenants?, "Journal of Accounting and Economics", Vol. 52, s. 178-202.

Demerjian P.R., Owens E.L. (2013), Measuring Financial Covenant Strictness in Private Debt Contracts, available at: http://ssrn.com/abstract=2232880.

Demiroglu C., James Ch.M. (2010), The Information Content of Bank Loan Covenants, "The Review of Financial Studies, Vol. 23, No. 10, pp. 3700-3737. 
Dichev I.D., Skinner D.J. (2002), Large-Sample Evidence on the Debt Covenant Hypothesis, "Journal of Accounting Research", Vol. 40, No. 4, pp. 1091-1123.

Gajdka J. (2002), Teorie struktury kapitału i ich aplikacja w warunkach polskich, Wydawnictwo Uniwersytetu Łódzkiego, Łódź.

Ismail R.H. (2014), The Determinants of Financial Covenants on Private Debt: The Case of Listed French Companies, "Research Journal of Finance and Accounting", Vol. 5, No. 15, pp. 176-183.

Jensen M.C., Meckling W.H. (1976), Theory of the Firm: Managerial Behavior, Agency Costs and Ownership Structure, "Journal of Financial Economics", Vol. 3, No. 4, pp. 305-360.

Moir L., Sudarsanam S. (2007), Determinants of financial covenants and pricing of debt in private debt contracts: the UK evidence, "Accounting and Business Research", Vol. 37, No. 2, pp. 151-166.

Myers S.C. (1977), Determinants of corporate borrowing, "Journal of Financial Economics", Vol. 5, pp. 147-175.

Reisel N. (2010), On the value of restrictive covenants: An empirical investigation of public bond issues, "Working Paper", Southern Methodist University.

Smith C.W., Warner Jr. and J.B. (1979), On financial contracting. An analysis of bond covenants, "Journal of Financial Economics", Vol. 7, pp. 117-161.

Śmieja N., Pauka M. (2013) Analiza konwenantów w obligacjach korporacyjnych emitowanych przez niebankowe spótki z branży finansowej, Annales Universitatis Mariae Curie-Skłodowska. Sectio H Oeconomia, Uniwersytet Marii Curie-Skłodowskiej, Vol. 47, No. 3, pp. 551-561.

Tappeiner F.T. (2010), Structure and determinants of financial covenants in leveraged buyouts, dissertation on Technische Universität München, http://www.mediatum.ub.tum.de/doc/997895/997895.pdf.

\section{STRUKTURA I RESTRYKCYJNOŚĆ KOWENANTÓW FINANSOWYCH W WARUNKACH EMISJI OBLIGACJI NOTOWANYCH NA CATALYST}

Streszczenie: $\mathrm{Cel}$-Celem artykułu jest ocena roli kowenantów finansowych stosowanych w warunkach emisji obligacji z rynku Catalyst oraz analiza rodzajów i cech tych kowenantów pod kątem ograniczania konfliktu pomiędzy właścicielami/menedżerami i obligatariuszami oraz ustalenie poziomu ich restrykcyjności.

Metodologia badania - W artykule przeprowadzono przegląd literatury, a następnie na bazie samodzielnie przygotowanej bazy kowenantów dla rynku Catalyst przeprowadzono analizę opisową i statystyczną.

Wynik - Wynikiem badań jest ustalenie, że polscy emitenci rzadko wykorzystują kowenanty finansowe, a jeśli już, to w większości bazując na kowenantach determinujących strukturę pasywów, a nie efektywność wykorzystywanego kapitału. Kowenanty oparte na wynikach mają bariery aktywacji ustawione na poziomie zerowym albo w obszarze strat. Liczba kowenantów i ich restrykcyjność nie jest powiązana z wielkością i z poziomem dźwigni finansowej emitentów.

Oryginalność/Wartość - W publikacjach naukowych rynek Catalyst był traktowano dotąd jako element systemu finansowego w Polsce. Dotąd brak jest badań poświęconych relacjom między uczestnikami tego rynku. Artykuł wypełnia tę lukę, prezentując wyniki oryginalnych badań, koncentrując szczególną uwagę na kowenantach finansowych, będących często przedmiotem badań na rynkach zagranicznych.

Słowa kluczowe: kowenanty, rynek obligacji Catalyst, obligacje, wskaźniki finansowe 
